\title{
DAMPAK VARIABILITAS IKLIM DAN MEKANISME ADAPTIF MASYARAKAT PETANI DI KAWASAN BERIKLIM KERING (KASUS DESA BORONUBAEN DAN DESA TAUNBAEN TIMUR, KABUPATEN TIMOR TENGAH UTARA, NUSA TENGGARA TIMUR)
}

\section{The Impact of Climate Variability and Adaptive Mechanisms of Community Farmers in Dry Climates Areas (The Case In Village Boronubaen And Taunbaen Timur Villages, Timor Tengah Utara District, East Nusa Tenggara)}

\author{
Eka Intan Kumala Putri ${ }^{1}$, Nurmala Katrina Pandjaitan ${ }^{2}$, Arya Hadi Dharmawan ${ }^{2}$, dan Rizka Amalia ${ }^{2}$ \\ ${ }^{1}$ Departemen Ekonomi Sumberdaya Lingkungan, FEM, Institut Pertanian Bogor \\ ${ }^{* *}$ Departemen Sains Komunikasi dan Pengembangan Masyarakat, FEMA, Institut Pertanian Bogor
}

\begin{abstract}
Climate variability led to a number of risks to the agricultural production process and the risk of shocks to the livelihood systems, which ultimately impat on the resilience of households farmer. The purpose of the research: (1) identify the impact of climate variability on regional farms and farmer households, 2) the ways to anticipate and type of adaptive response of households farmer as effort to survive, 3) the direction change of the socio-economic, institutional and socio-ecological that accompany the adaptation process at household and community farmerslevel, and 4) to formulate suggestionthe adaptation mechanisms of households farmerin response the climate variability, which impacts on food security temporarily. The results showed in 2015, 2nd study areas is long drought.The Changes in productivity of rice crops due to climate variability in the Taunbaen Timurvillagehigher than Boronubaenvillage. The condition is supported by calculations Livelihood Vulnerability Index (LVI) showed household farmers in the Taunbaen Timur is more vulnerable than Boronubaen village household farmers. Food insecurity in the two villages is not only due to drought and pests, but also due to the high dependence on rice, making farming community poorer. To improve food security and resilience of householdfarmers income, need to increase public physical capital.
\end{abstract}

Keywords: climate variability, vulnerability, resilience, food insecurity, livelihood.

\begin{abstract}
ABSTRAK
Variabilitas iklim menyebabkan sejumlah risiko terhadap proses produksi pertanian dan risiko guncangan pada sistem penghidupan, yangakhirnya berdampak pada resiliensi rumahtangga petani. Tujuan penelitian yaitu (1) mengidentifikasidampak variabilitas iklim pada kawasanusahatani dan rumahtangga petani, 2)cara-cara mengantisipasi dan tipe respons adaptif rumahtangga petani dalam upaya bertahan hidup, 3) arah perubahan sistem sosio-ekonomi, kelembagaan dan sosio-ekologi yang menyertai proses adaptasi di tingkat rumahtangga dan komunitas petani, dan 4) memformulasi usulan mekanisme adaptasi rumahtangga petani dalam merespon variabilitas iklim, yang berdampak terhadap ketahanan pangan temporer. Hasil penelitian menunjukkan pada tahun 2015, ke-2 desa penelitian, mengalami kekeringan yang cukup panjang. Perubahan produktivitas tanaman padi akibat variabilitas iklim di Desa Taunbaen Timur lebih tinggi daripada di Desa Boronubaen. Kondisi tersebut didukung oleh perhitungan Livelihood Vulnerability Index (LVI) menunjukkan petani di Desa Taunbaen Timur lebih rentan dari pada petani Kelurahan Boronubaen terhadap variabilitas iklim. Kerawanan pangan di dua desa penelitian bukan hanya disebabkan oleh kekeringan dan hama penyakit, tetapi juga akibat ketergantungan beras yang tinggi, membuat komunitas petani semakin miskin.Untuk meningkatkan ketahanan pangan dan resiliensi nafkah rumahtangga petani, perlu peningkatan modal fisik yang bersifat publik.
\end{abstract}

Kata kunci: variabilitas iklim, kerentanan, resiliensi, kerawanan pangan, nafkah.

\section{PENDAHULUAN}

\section{Latar Belakang}

Variabilitas iklim menunjukkan adanya siklus cuaca dan curah hujan yang mengalami pergeseran dan ketidakpastian, kadang turun hujan sangat deras ketika musim hujan dan kekeringan ekstrim saat musim kemarau. Kondisi ini menyebabkan sejumlah risiko terhadap berbagai aktivitas, yaitu proses produksi pertanian menurun dan produktivitas lahan semakin tidak terprediksi sehingga risiko guncangan tidak menentu pada sistem penghidupan yang berdampak pada vulnerabilitas rumahtangga, yang pada akhirnya mempengaruhi bagaimana resiliensipetani dalam menghadapinya.
Pertanyaanpenelitian ini adalah bagaimana vulnerabilitas petani di kawasan berlahan kering dalam menghadapi variabilitas iklim?Seberapa besar tingkatresiliensi (lapisanlapisan) rumahtangga petani di kawasan beriklim kering?dan bagaimana rumahtangga petani tersebut dapat bertahan hidup dan membangun resiliensi dalam rumahtangga dan di level komunitasnya? Secara spesifik, penelitian ini untuk menjawab pertanyaan: 1) Sedalam apakah dampak variabilitas iklimterhadap sistem livelihood masyarakat? 2) Bagaimanakah cara-cara mengantisipasi dan tipe respons adaptif (aksi adaptasi atau strategi survival) rumahtangga petani dalam upaya bertahan hidup dan menyesuaikan diri menghadapi dampak variabilitas iklim/krisis? 3) Bagaimanakah arah perubahan sistem sosio-ekonomi, kelembagaan dan sosio- 
ekologi yang menyertai proses-proses adaptasi tersebut di tingkat rumahtangga dan komunitas petani? dan 4) Bagaimanakah mekanisme adaptasi (rekayasa kelembagaan, teknologi, organisasi sosial, ekonomi, budaya) rumahtangga petanidalam merespon variabilitas iklim yang berdampak terhadap ketahanan pangan temporer?

\section{Tujuan Penelitian}

Tujuan penelitian ini adalah: 1) Mengidentifikasi sedalam apa dampak variabilitas iklim pada kawasan danlahan usahatani, 2) Mengidentifikasi cara-cara mengantisipasi dan tipe respons adaptif (aksi adaptasi atau strategi survival) rumahtangga petanidalam upaya bertahan hidup dan menyesuaikan diri menghadapi dampak variabilitas iklim/krisis ekologi, 3) Mengidentifikasi arah perubahan sistem sosio-ekonomi, kelembagaan dan sosio-ekologi yang menyertai proses-proses adaptasi tersebut di tingkat rumahtangga dan komunitas petani,4) Mengembangkan usulan tentang mekanisme adaptasi rumahtangga petanidalam merespon variabilitas $\mathrm{iklim} / \mathrm{krisis}$ ekologi yang berdampak terhadap ketahanan pangan temporer.

\section{METODE PENELITIAN}

Penelitian ini dilakukan di 2 (dua) desa, yaitu Desa Boronubaen (mewakili desa dataran rendah) dan Desa Taunbaen Timur (mewakili desa dataran tinggi, Kecamatan Biboki Utara, Kabupaten Timor Tengah Utara (TTU), Nusa Tenggara Timur (NTT). Pemilihan responden dengan teknik stratified random sampling sebanyak 150 responden. Penelitian ini menggunakan pendekatan kualitatif dan kuantitatif. Data primer diperolehdengan cara survei, in depth interview, pengisian kuesioner, dan FGD. Data sekunder diperoleh dari BPS Kab. TTU dan Badan Meteorologi, Klimatologi, dan Geofisika (BMKG) Provinsi NTT.Analisis deskriptif kualitatif dan analisis kuantitatif dengan Change in Productivity (CiP), Loss of Earning (LoE), dan Livelihood Vulnerability Index (LVI), digunakan dalam penelitian ini.

\section{HASIL DAN PEMBAHASAN}

\section{Fakta-Fakta Terjadinya Variabilitas Iklim di Desa Boronubaen dan Desa Taunbaen Timur}

Fluktuasi curah hujan yang paling ekstrim terjadi di Kecamatan Biboki Utara yaitu pada tahun 2002, 2003, dan 2008 (gambar 1). Akibat pola hujan yang tidak menentu tersebut menimbulkan ancaman hama dan penyakit yang menyerang tanaman padi dan tanaman perkebunan. Hama yang paling sering menyerang daerah ini adalah hama belalang dan penyakit bule/'blast', yang dicirikan tanaman Padi jelang panen mendadak akan layu lunglai sehingga bulir Padi kosong. Hal ini jelas merugikan petani tidak saja gagal panen, tetapi juga penghasilan petani hilang.

Ada dua gejala-fisik yang menandai hadirnya variabilitas iklim di suatu kawasan, yaitu pertama munculnya hama dan penyakit tanaman terkait perubahan cuaca serta perubahan lingkungan (banjir ataupun kekeringan). Kedua, tidak terkendalinya fluktuasi iklim dimana musim penghujan dan musim kering tidak beraturan polanya setiap tahun. Para petani di empat desa kasus menganggap dua gejala-fisik tersebut sebagai penanda hadirnya (dampak buruk) variabilitas iklim.

Dampak Perubahan Variabilitas Iklim Terhadap Sistem Livelihood Masyarakat Petani di Kawasan Beriklim Kering Sumber nafkah pokok yang dominan di Desa Taunbaen Timur

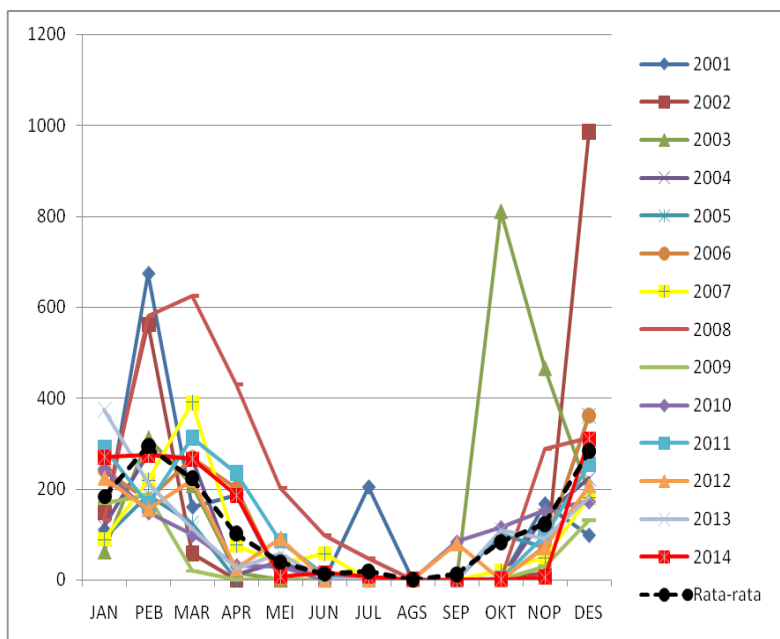

Gambar 1. Data Perubahan Pola Hujan di Kabupaten TTU (Tahun 2001-2014)

dan Desa Boronubaen berasal dari pertanian Padi. Masyarakat petani pada ke-2 desa tersebut berusaha mempertahankan kehidupan dan meningkatkan resiliensi rumahtangga mereka dengan melakukan diversifikasi mata pencaharian dan melakukan pekerjaan selain on farm, yaitu pekerjaan off farm dan non farm. Walaupun demikian, untuk rumahtangga lapisan bawah juga berusaha meningkatkan resiliensinya dengan "bantuan dari negara (state aids)" (lihat gambar 2).

Struktur pengeluaran rumahtangga, baik di Desa Taunbaen Timur maupun di Desa Boronubaen, sama-sama memiliki pengeluaran pangan yang relatif tinggi, sehingga dapat ditunjukkan bahwa ke-2 desa masih belum bebas dari kemiskinan, khususnya bagi rumahtangga di Desa Taunbaen Timur (gambar 3)

Selanjutnya, jika disandingkan rata-rata penghasilan dan pengeluaran rumahtangga petani pemilik, baik di Desa Boronubaen maupun di Desa Taunbaen Timur, surplus penghasilan dialami oleh rumahtangga petani lapisan atas dan menengah dan defisit penghasilan terjadi pada rumahtangga petani lapisan bawah. Dari pernyataan tersebut dapat dinyatakan bahwa rumahtangga petani, baik di lapisan atas maupun menengah, di ke-2 lokasi penelitian mampu melakukan konsolidasi nafkah yang diperlukanuntuk mengantisipasi keadaan krisis, sedangkan rumahtangga petani lapisan bawah merupakan rumahtangga paling rentan atas dampak variabilitas iklim karena rumahtangga ini tidak mampu mengkonsolidasi nafkah saat krisis.

\section{Kerentanan Nafkah Rumahtangga Akibat Variabilitas Iklim}

Desa Taunbaen Timur memiliki nilai LVI yang lebih tinggi daripada Desa Boronubaen. Nilai LVI Desa Taunbaen Timur sebesar 0,4218 sedangkan Desa Boronubaen memiliki nilai LVI sebesar 0,39824. Jika batas ambang kerentanan $=0,5$ maka hal ini menunjukkan bahwa secara keseluruhan Desa Taunbaen Timur memiliki tingkat kerentanan yang relatif lebih besar terhadap dampak variabilitas iklim kekeringan dibandingkan dengan Desa Boronubaen.

\section{Ketersediaan Pangan, Pemanfaatan dan Akses Pangan dalam Komunitas}

Masalah kelangkaan pangan dan kemiskinan di Desa Boronubaen dan Desa Taunbaen Timur, sudah dirasakan 


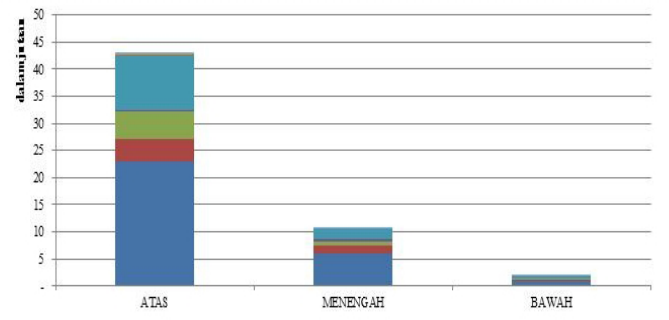

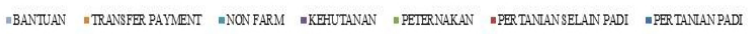

(a) Desa Taunbaen Timur

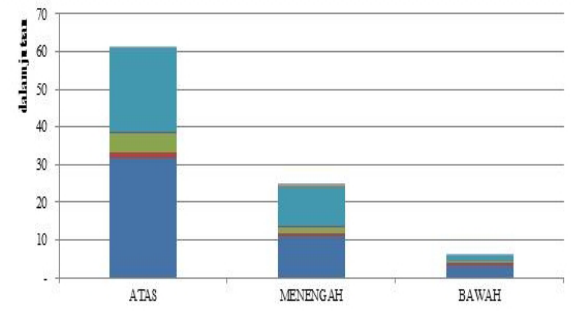

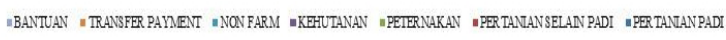

(b) Kelurahan Boronubaen

Gambar 2. Rata-rata Penghasilan Rumahtangga Petani di (a) Desa Taunbaen Timur dan (b) Kelurahan Boronubaen 2014-2015

sejak lama, yang disebabkan oleh ketidakmampuan ekonomi maupun adanya serangan hama yang merusak hasil panen sehingga gagal panen. Sejak Beras diperkenalkan pemerintah maka warga di ke-2 desa penelitian menjadi sangat tergantung pada Beras. Jagung, Kacang hutan, Kacang Merah, Ubi Kayu dan Ubi Jalar adalah makanan yang sebelumnya sudah menjadi pola makan masyarakat, namun setelah mereka mengenal beras maka selanjutnya beras menjadi bahan pangan pokok yang selalu dikonsumsi walaupun harganya mahal. Masyarakat disana sekarang mayoritas mengkonsumsi raskin yang dicampur dengan Jagung.

\section{Mekanisme Adaptif Petani dalam Merespon Variabilitas Iklim}

Rumahtangga petani di kedua desa penelitian memanfaatkan 5 (lima) modal nafkah untuk meningkatkan resiliensi dalam merespon variabilitas iklim, khususnya menghadapi kekeringan.

Berdasarkan gambar 4 ditunjukkan bahwa modal fisik di Desa Boronubaen mempunyai nilai yang tinggi dibanding modal sumberdaya alam (SDA), sosial, finansial dan modal sumberdaya manusia (SDM). Hal ini disebabkan karena cukup tingginya ketersediaan, kemudahan mengakses dan memanfaatkan berbagai sarana prasarana listrik, jalan dan air kolektif, melalui program PAMSIMAS. Sementara itu, modal SDA di Desa Taunbaen Timur mempunyai nilai tinggi karena

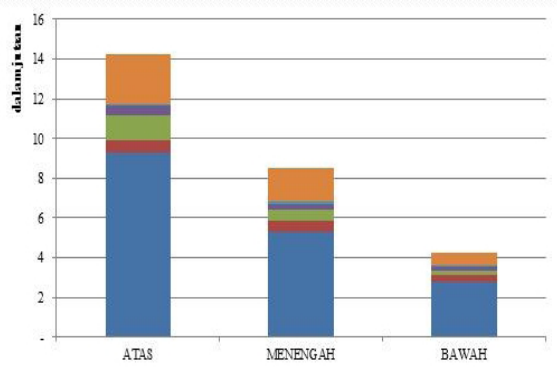

"LARNYA:KESEHATAN, ROKOK, SRIH PNANG, PULSA =SOSIAL "PAKAIAN "PENDDIKAN =ENERGI "PANGAN

(a) Desa Taunbaen Timur wilayahnya secara spasial dekat dengan hutan dan sungai yang merupakan sumberdaya yang memungkinkan kemudahan mengakses dan memanfaatkan hutan dan sungai tersebut untuk menghadapi krisis.

Sementara itu, walaupun modal sosial di ke-2 lokasi penelitian bernilai kecil, yang menunjukkan bahwa modal sosial formal tidak besar dalam mendukung resiliensi nafkah rumahtangga petani, tetapi pada kenyataannya terdapat peran kelembagaan informal (marga, tobe, raja, papa lele) yang sangat membantu mereka saat kritis. Gotong royong masih dikenal di ke-2 desa tersebut, dengan beberapa istilah seperti neuptabua (kerja bakti dalam lingkup luas), auoro (saling membantu dalam lingkup kecil) yang juga mendukung resiliensi nafkah rumahtangga petani di Desa Taunbaen Timur dan Desa Boronubaen.

Selain lima modal nafkah yang bersifat publik, rumahtangga petani juga memanfaatkan lima modal nafkah yang bersifat personal untuk membangun resiliensi rumahtangganya. Selanjutnya, gambar 5 menunjukkan bagaimana modal nafkah personal berperan di ke-2 desa penelitian tersebut.

Dari kelima modal nafkah private yang dimiliki oleh rumahtangga petani di dua Desa penelitian, modal Sumberdaya alam di kedua daerah penelitian bernilai paling besar dibanding dengan modal nafkah lainnya karena masingmasing rumahtangga di lokasi penelitian mempunyai lahan kebun dengan luas rata-rata 0,3 Ha di Desa Taunbaen Timur

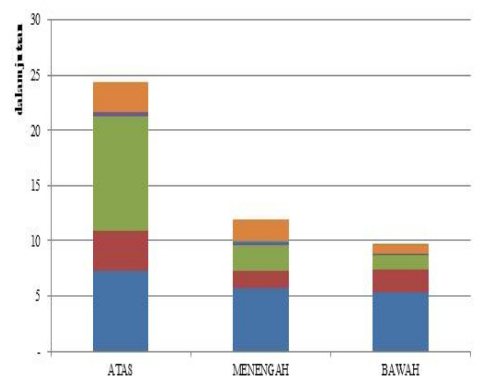

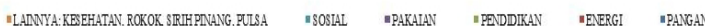

(b) Kelurahan Boronubaen

Gambar 3. Rata-rata Pengeluaran Rumahtangga Petani di (a) Desa Taunbaen Timur dan (b) Kelurahan Boronubaen, 2014-2015 


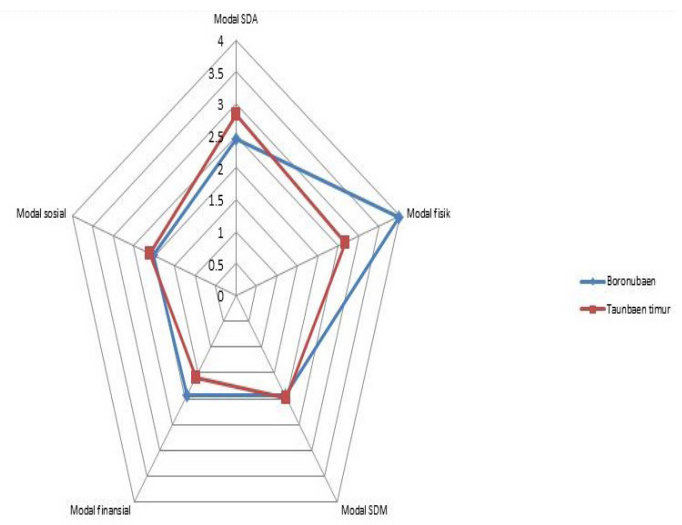

Gambar 4. Modal Nafkah Publik di Dua Lokasi Penelitian, 2015

dan 0,19 Ha di Kelurahan Boronubaen yang dapat diakses dan dimanfaatkan untuk membangun resiliensi nafkah rumahtangga petani.

\section{Bentuk-Bentuk Tindakan Sosio-Ekologi-Ekonomi dalam Merespon Dampak Variabilitas Iklim di Kedua Lokasi Penelitian}

Variabilitas iklim yang telah dibahas pada sub sebelumnya, dimana variabilitas iklim tersebut megakibatkan penurunan produksi pertanian sehingga berdampak pada penurunan penghasilan rumahtangga petani di ke-2 daerah penelitian. Dampak negatif dari variabilitas iklim yang dirasakan oleh rumahtangga petani di ke-2 desa penelitian disikapi dengan cara membangun berbagai mekanisme adaptasi dan strategi adaptasi. Terdapat 3 (tiga) strategi adaptasi digunakan oleh rumahtangga petani di kedua desa penelitian secara bersamaan, yang dapat dilihat pada Gambar 6 berikut ini.

Strategi adaptasi yang dominan dipersepsikan menjadi strategi adaptasi yang mempunyai kebertahanan tinggi dalam menghadapi dampak variabilitas iklim adalah strategi adaptasi sosial. Hal ini disebabkan strategi adaptasi sosial meliputi tindakan-tindakan, seperti pemanfaatan bantuan pemerintah, pemanfaatan jaringan pertetanggaan, pemanfaatan jaringan kekeluargaan, remittance, pemanfaatan jaringan LSM, aksi kolektif masyarakat desa, dan pemanfaatan jaringan keagamaan yang bisa diakses dan dimanfaatkan secara mudah oleh rumahtangga petani yang mengalami dampak buruk dari
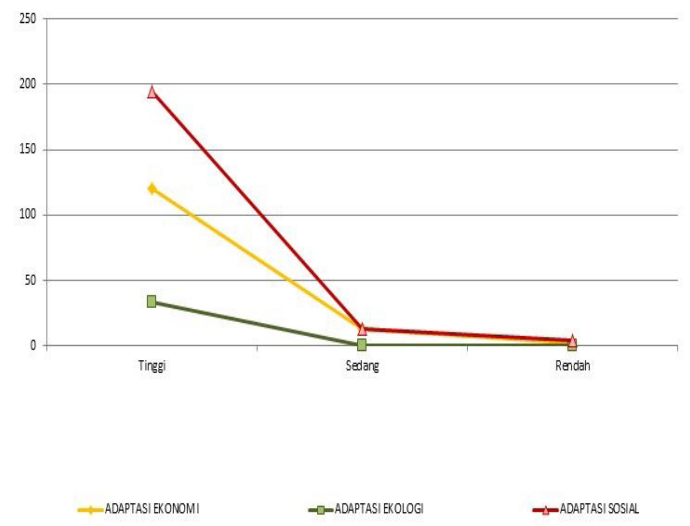

(a) Desa Taunbaen Timur

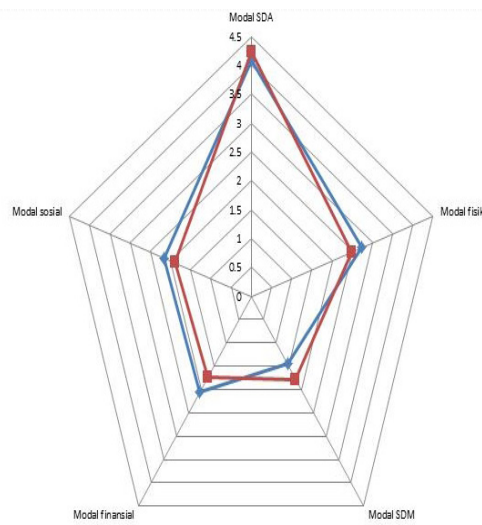

—-

Gambar 5. Modal Nafkah Private di Dua Desa Penelitian, 2015

lalu melalui doa-doa yang dipanjatkan oleh warganya. Pada masa kini ketersediaan pangan lebih mengandalkan bantuan dari negara berupa raskin (beras miskin) atau skema-skema bantuan pemerintah lainnya, dan 2) bergesernya bentuk networking atau jejaring social secara tradisional yang dimasa lalu menjamin keamanan sosial warga setempat kepada bentuk social networking baru modern. Melemahnya ikatan-ikatan sosial pertetetanggaan (neighborhood based network), ikatan sosial territorial, ikatan sosial keagamaan, yang selama ini menjamin keamanan sosial warga setempat, saat ini sudah tergantikan networking yang lebih modern seperti pada rentenir kemudian juga networking dengan papalele dalam hal perdagangan.

\section{Usulan Mekanisme Adaptasi Rumahtangga Petani di Kawasan Beriklim Kering dalam Merespon Variabilitas Iklim}

Berbagai mekanisme dan strategi adapatasi telah dilakukan oleh rumahtangga petani dalam rangka bertahan dari kondisi yang terjadi akibat variabilitas iklim. Namun perubahan iklim merupakan salah satu fenomena global yang tidak mungkin dihindari dan dalam jangka waktu panjang akan terus mengancam sistem penghidupan petani yang sangat tergantung dengan kondisi alam (baca: iklim). Oleh karena itu, berbagai skenario dipersiapkan untuk menghadapi berbagai dampak negatif dari perubahan iklim sehingga ketahanan nafkah rumahtangga terus meningkat dan mampu beradaptasi
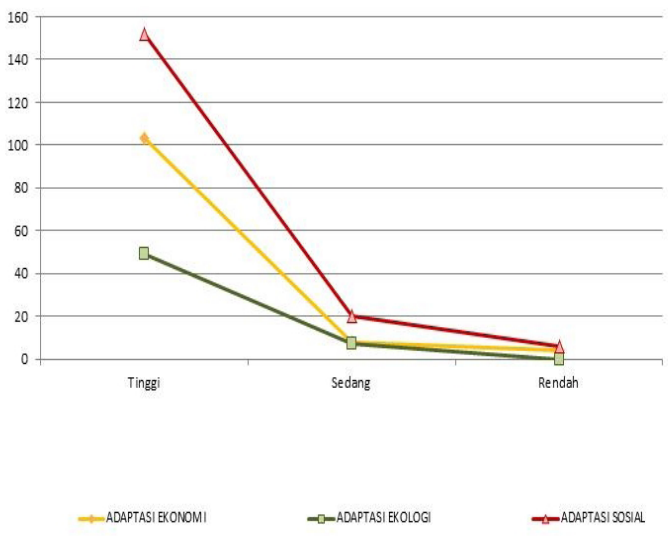

(b) Kelurahan Boronubaen

Gambar 6. Persepsi Rumahtangga Petani tentang Mekanisme Adaptasi dalam Menghadapi Dampak Buruk Variabilitas Iklim di Desa Taunbaen Timur (a) dan di Kelurahan Boronubaen (b) 


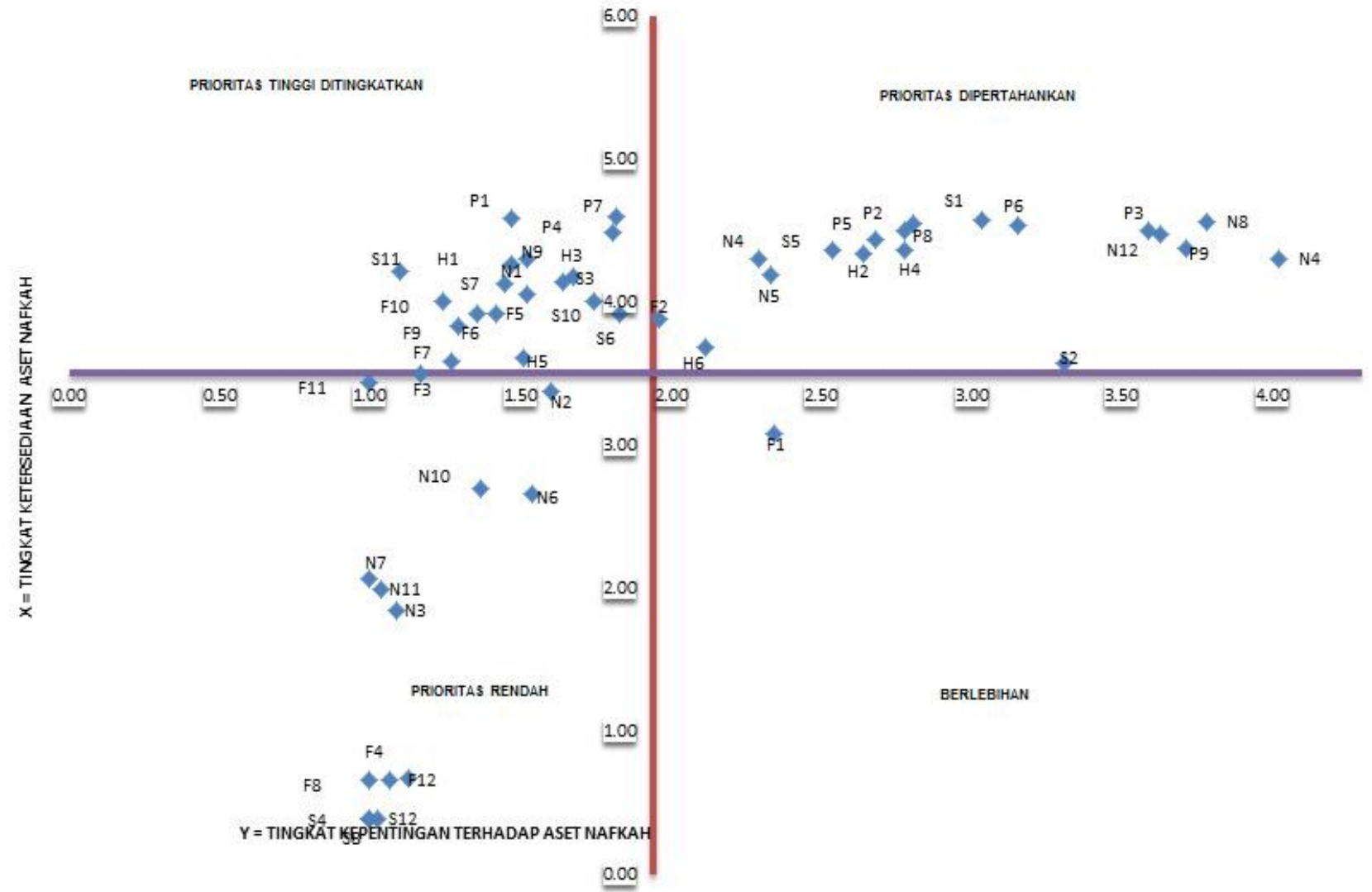

Gambar 7. Hubungan Ketersediaan dan Kepentingan Aset Nafkah Rumahtangga yang Bersifat Publik di Desa Taunbaen Timur

dengan perubahan yang terjadi.

Dari ke-5 modal nafkah di kedua lokasi penelitian, prioritas yang paling banyak sebagai mekanisme adaptasi dalam merespon variabilitas iklim adalah modal fisik, yaitu berupa ketersediaan, kemudahaan memanfaatkan dan mengakses listrik, jalan dan air milik komunitas (PAMSIMAS). Bagi rumahtangga di ke-2 lokasi penelitian keberadaan PAMSIMAS sangat dibutuhkan sebagai pemenuhan kebutuhan minum dan mandi serta kebutuhan sehari-hari, khususnya ketika terjadi kekeringan. Bagi masyarakat tani, modal fisik (lahan, alat-alat pertanian, ternak dan barang-barang berharga) adalah sumber

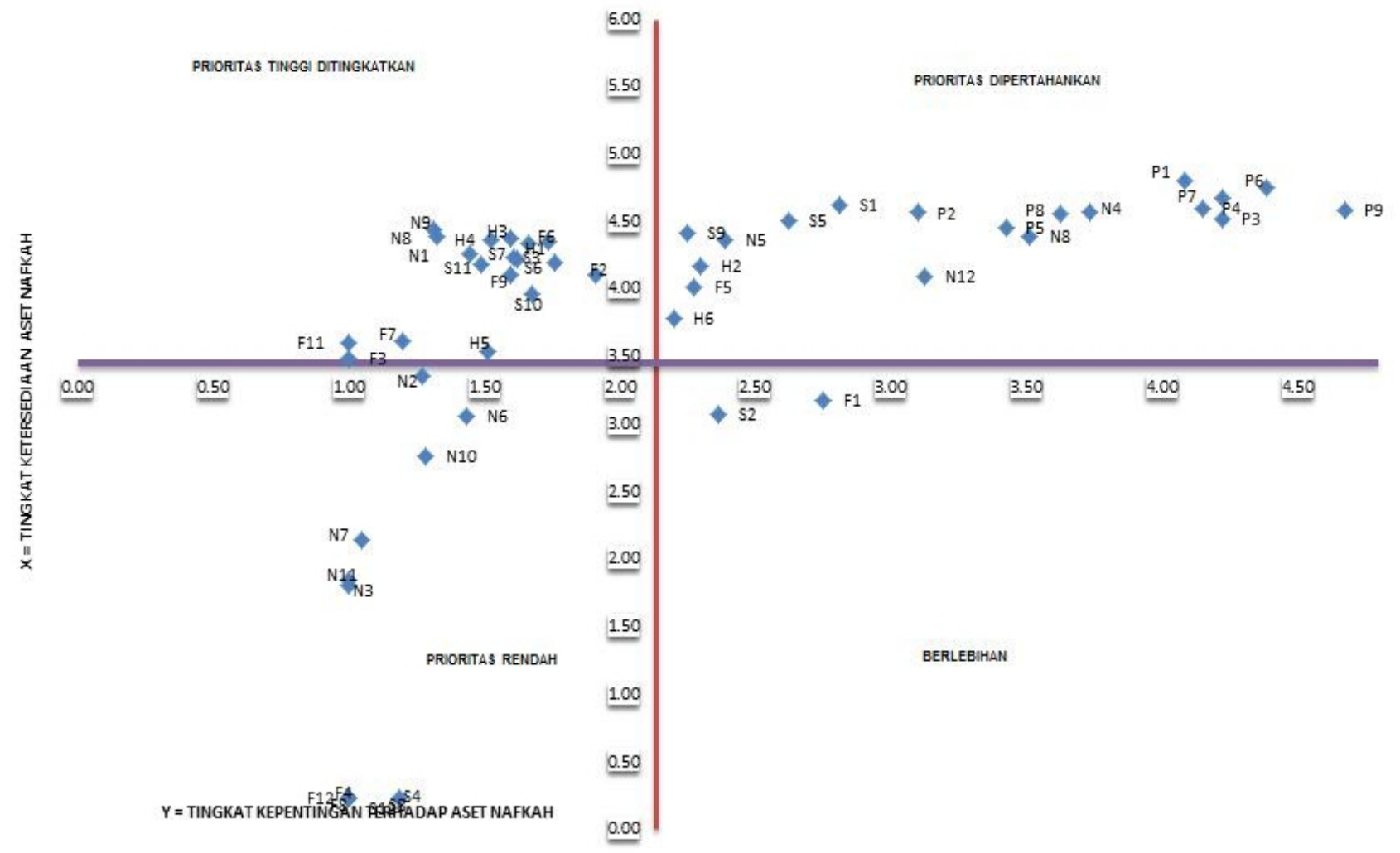

Gambar 7. Hubungan Ketersediaan dan Kepentingan Aset Nafkah Rumahtangga yang Bersifat Publik di Desa Boronubaen 
bertahan hidup yang penting. Modal inilah yang digunakan untuk melawan kerentanan atas hadirnya dampak buruk dari variabilitas iklim.

\section{Implikasi Penelitian}

Berkaca pada hasil studi di dua desa penelitian, yaitu Kelurahan Boronubaen dan Desa Taunbaen Timur, diusulkan beberapa strategi penguatan resiliensi nafkah rumahtangga petani. Diasumsikan bahwa variabilitas iklim semakin tidak dapat dielakkan pada satuan-satuan lokal, karenanya maka strategi adaptif atau mekanisme adaptasi masing-masing rumahtangga adalah hal yang perlu dilakukan, yaitu:

1. Pada masyarakat Desa Taunbaen Timur yang masih kolektif dan relatif terisolasi dari modernitas, maka pemeliharaan dan penguatan kelembagaan solidaritas sosial pangan asli seperti papalele, kelembagaan gotong-royong, lopo, lumbung padi, dan hutang piutang. Modal berupa trust atau kepercayaan diantara para petani dan norma kerjasama yang terbentuk harus dipelihara. Bila saatnya, modernitas telah memasuki ruang-ruang kehidupan masyarakat desa, maka sedikit-demi-sedikit institusi modern seperti berbagai bantuan dari negara dalam bentuk raskin (beras miskin) dan atau berbagai bentuk skema jaminan sosial dari negara lainnya, bisa menggantikannya.

2. Pada masyarakat Boronubaen, yang merupakan masyarakat rural urban yang tetap attached di dalam struktur sosial-ekonomi masyarakat pedesaan, maka perluasan kesempatan kerja non pertanian menjadi keniscayaan. Pada masyarakat yang mengandalkan mekanisme adaptasi dengan pola nafkah ganda yang menonjol, maka keberadaan dan ketersediaan sektor non pertanian menjadi sangat perlu. Bila tidak, maka migrasi, berhutang, dan berharap bantuan akan menjadi strategi adaptif yang sesungguhnya adalah strategi yang memprihatinkan.

3. Dampak buruk variabilitas iklim sejatinya dapat diantisipasi oleh masyarakat petani atau rumahtanggarumahtangga petani di daerah seperti apapun, termasuk petani di Boronubaen dan di Taunbaen Timur. Perbedaan mekanisme adaptif yang dilakukan oleh masing-masing petani di ke-2 desa tersebut sangat tergantung pada; (1) besarnya atau dalamnya dampak buruk variabilitas iklim; (2) keberadaan lima jenis modal yang tersedia atau di dalam kontrol rumahtangga petani; (3) kesiapan secara sosial-ekonomi dan ekologis rumahtangga petani dengan segala mekanisme atau strategi adaptif yang dimilikinya.

\section{KESIMPULAN DAN SARAN}

\section{Kesimpulan}

Desa Taunbaen Timur dan Kelurahan Boronubaen mengalami variabilitas iklim berupa kekeringan yang cukup panjang pada tahun 2015 yang mengakibatkan hama penyakit yang menyerang tanaman Padi, sehingga gagal panen dan mengakibatkan menurunnya produktivitas Padi. Perubahan produktivitas tanaman Padi akibat variabilitas iklim di Desa Taunbaen Timur lebih tinggi daripada di Kelurahan Boronubaen. Dari LVI menunjukkan bahwa paa petani di Desa Taunbaen Timur lebih rentan terhadap variabilitas iklim dari pada petani di Kelurahan Boronubaen. Kerawanan pangan dike-2 desa penelitian bukan hanya disebabkan oleh kekeringan, banjir, hama, dan kemiskinan tetapi juga akibat ketergantungan pada beras yang membuat komunitas semakin miskin.

\section{Saran}

Untuk meningkatkan ketahanan pangan dan resiliensi nafkah rumahtangga petani, perlu peningkatan modal fisik yang bersifat publik.

\section{DAFTAR PUSTAKA}

Adger, Neil., W. 1999. Social Vulnerability to Climate Change and Extremes in Coastal Vietnam. World Development Vol. 27, No.2, Pp. 249-269. Elsevier Science, Ltd. UK.

Barnett, Jon and W.Neil Adger. 2007. Climate Change, Human Security and Violent Conflict. Political Geography. Vol.26. Pp. 639-655. Elsevier Science, Ltd. UK.

Dowell, Mc., Julia Z and Jeremy J. Hess. 2012. Accessing Adaptation: Multiple Stressors on Livelihoods in the Bolivian Highlands Under A Changing Climate. Global Environmental Change Vol 22. Pp. 342-352. Elsevier Science, Ltd. UK.

Fran H. Norris, Susan P. Stevens, Betty Pfefferbaum, Karen F.Wyche and Rose L Pfefferbaum. 2008. Community resilience as a metaphor, theory, set of capacities and strategy for disaster readiness. Am J Community Psychology (2008) 41: 127-150.

Heikkila, T, Gerlak, A.K., Bell A.R., Schmeier, S. 2013. Adaptation in Transboundary River Basin: Linking Stressors and Adaptive Capacity Within the Mekong River Commission. Environmental Science and Policy, Vol.25, Pp. 73-82. Elsevier Science, Ltd. UK.

Jennifer kofkin rudkin. 2003. Community Psychology. Guiding principles and orienting concepts. Pearson education, inc.

Munang, R., Ibrahim Thiaw, Keit Alverson, Musonda Mumba, Juan Liu, and Mike Rivington. 2013. Climate Change \& Ecosystem-Based Adaptation: A New Pragmatic Approach to Buffering Climate Change Impacts. Current opinion in Environmental Sustainability Vol. 5. Pp. 67-71. Elsevier Science, Ltd. UK.

Osbahr, H., Twyman, C., Adger, W.N., Thomas, D.S.G. 2008. Effective Livelihood Adaptation to Climate Change Disturbance: Scale Dimensions of Practice in Mozambique. Geoforum, Vol.39, Pp.1951-1964. Elsevier Science, Ltd. UK.

Wilson, G.A., 2013. Community Resiliensi, Policy Corridors and the Policy Challenge. Land Use Policy, vol. 31, Pp.298-310. Elsevier Science, Ltd. UK

\section{UCAPAN TERIMAKASIH}

Pada kesempatan ini kami mengucapkan banyak terimakasih DIKTI, petani di Desa Taunbaen Timur dan Kelurahan Boronubaen, Kabupaten Timor Tengah Utara, Nusa Tenggara Timur; dan berbagai pihak yang tidak mungkin disebutkan satu per satu disini atas terlaksananya penelitian ini. 